\title{
INFLUENCE OF COMPACTION METHODS ON FUNCTIONAL AND STRUCTURAL PERFORMANCE OF PERVIOUS CONCRETE
}

\author{
Ashfaque Ansari \\ Research Scholar, Visvesavarya National Institute of Technology, \\ Nagpur, Maharashtra, India \\ Mukund Mahajan \\ Professor, Visvesavarya National Institute of Technology, \\ Nagpur, Maharashtra, India
}

\begin{abstract}
Performance of pervious concrete mainly depends on strength and its interconnected macro-pore structure which allow water to percolate through. A careful mix design is required, to achieve mix of desired porosity and strength. Due to variation in specimen preparation technique a lots of variations were observed in performance of pervious concrete, this can be due to variation in mixing procedure and method of compaction. Extensive researches in the past have been done on different mix parameters that influence the structural and functional performance of pervious concrete. However, the compaction method is one of the key parameter, is still a conjecture. The main objective of this study was to study the effect of compaction methods on performance of pervious concrete. Specimens were prepared with four gradations of aggregates with constant water to cement ratio $(W / C)$ of 0.32 and three types of aggregate to cement ratio $(A / C)$ ratios of $3.5,4.0 \& 4.5$. All the mixtures were designed as per American Concrete Institute (ACI) guidelines with three different compaction methods namely; rodding, proctor hammer and pneumatic vibration. Effects of compaction methods on structural as well as functional performance of pervious concrete were studied. Results demonstrate the influence of compaction methods on different pervious concrete specimens.
\end{abstract}

Keywords: Pervious concrete, compaction, aggregate-cement ratio, proctor hammer, pneumatic vibration, porosity, compressive strength

Cite this Article: Ashfaque Ansari and Mukund Mahajan, Influence of Compaction Methods on Functional and Structural Performance of Pervious Concrete, International Journal of Civil Engineering and Technology, 11(7), 2020, pp. 94-105. https://iaeme.com/Home/issue/IJCIET?Volume=11\&Issue=7 


\section{INTRODUCTION}

Pervious concrete is a concrete differ from ordinary concrete in terms of porosity and application. Pervious concrete is a zero slum concrete with high porosity and interconnected voids that allows flow of liquid media through its interconnected pores. Due to porous nature of pervious concrete, it depicted lower density and structural strength as compared to conventional concrete [1], [2]. A variety of benefits can be achieved through use of pervious concrete in horizontal infrastructure like, pavements and footpaths. Previous studies proved that, use of pervious concrete in pavement can reduce stormwater runoff significantly as well as can improve the quality of stormwater runoff by minimizing the concentration of heavy metal like zinc, lead, copper etc. [3], [4], [5], [6], [7], [8]. Other benefits that can be achieved through pervious concrete in pavement sector are; reduced risk of pollution from storm-water, reduced Urban Heat Island (UHI) effect, less glare at night, more skid resistance etc. Use of pervious concrete contributes to save the environment from the effect of development [9], which is one of the major issue among the environmentalist all over the world [10], [11], [12].

Pervious concrete consists of conventional concrete materials like, cement, aggregates and water, with very less or no fine aggregates. Controlled amount of Water-cement (W/C) ratio and aggregate-cement $(\mathrm{A} / \mathrm{C})$ ratio are the key factors which affect the performance of pervious concrete [13], [14], [15]. Type of aggregates and grading are also important factor that influence the property of pervious concrete [15], [16]. Use of admixtures like plasticizers and air entraining agents also improves the structural and functional property of pervious concrete [1], [2], [17]. Compaction is another important aspect, which directly influences the performance of pervious concrete and requires to be standardized, as there is no standard procedure of compaction is available till date. A very few literatures are available in the domain of compaction effect on pervious concrete and this topic still not explored in depth. Few previous studies demonstrated that compaction method and compaction energy supplied to pervious concrete affects the structural and functional properties of pervious concrete [18], [19]. Less compaction reduces the compressive strength and high compaction reduces the porosity [19], [20], hence to balance this trade-off a perfect amount of compaction effort is required in production of pervious concrete with desired strength and porosity.

To achieve all the benefits of pervious concrete, it is necessary that, pervious concrete should be designed and compacted properly [21], [22], [23]. For obtaining desired results it is very important to pay close attention to mix design method, production, placement, compaction and curing of pervious concrete [1].

Roller compaction (static or pneumatic) is the compaction technique used in most of pavement construction. The main aim of compaction is to set the aggregates between the proper gaps and to make the bond between the aggregates, but excessive compaction would reduce the porosity of pervious concrete [20]. An effort has been made by this research to mimicries the compaction method of field in the laboratory. As compaction procedure of pervious concrete in the field is differ from ordinary concrete, it is important to consider the effect of field compaction in the laboratory. To achieve uniform compaction among all the samples three types of compaction methods a) rodding, b) proctor hammer and c) pneumatic vibration were employed in the laboratory for preparation of different specimens.

\section{OBJECTIVE}

The main objective of this study was to determine the most appropriate method of compaction that can produce pervious concrete specimen of optimum performance and, to compare the structural and functional performance of pervious concrete specimens, prepared using different compaction methods. 


\section{MATERIALS AND METHODS}

To achieve the objective of this study, test specimens were casted using three different compaction techniques and compared the values with the design values.

All the mixes were designed using standard method of ACI [1] for mix design of pervious concrete.

\subsection{Materials}

This investigation was done on twelve different mixtures which consisted of four different gradations of aggregate namely G1, G3, G4 and G7. In the preparation of specimens three levels of $\mathrm{A} / \mathrm{C}$ ratio; $3.5,4.0$ and 4.5 were used with constant $\mathrm{W} / \mathrm{C}$ ratio of 0.32 , e. All the twelve mixtures were given compaction with three different types of compaction techniques i.e. total 36 types of samples were evaluated (Table 1). The mixture gradations G1 and G3 were of single sized aggregate gradation, while G4 dense gradation and G7 was of ternary aggregate gradation as given below

- G1: single sized aggregate passing $6.7 \mathrm{~mm}$ and retained on $4.75 \mathrm{~mm}$ IS sieve

- G3: single sized aggregate passing $12.5 \mathrm{~mm}$ and retained on $10 \mathrm{~mm}$ IS sieve

- G4: $25 \%$ passing $20 \mathrm{~mm}$ and retained on $12.5 \mathrm{~mm}+25 \%$ passing $12.5 \mathrm{~mm}$ and retained on $10 \mathrm{~mm}+25 \%$ passing $10 \mathrm{~mm}$ and retained on $6.7 \mathrm{~mm}+25 \%$ passing $6.7 \mathrm{~mm}$ and retained on $4.75 \mathrm{~mm}$ IS sieve

- G7: $50 \%$ passing $12.5 \mathrm{~mm}$ and retained on $10 \mathrm{~mm}+25 \%$ passing $10 \mathrm{~mm}$ and retained on $6.7 \mathrm{~mm}+25 \%$ passing $6.7 \mathrm{~mm}$ and retained on $4.75 \mathrm{~mm}$ IS sieve

Table 1 Mixture Details

\begin{tabular}{cccccccc}
\hline \multirow{2}{*}{ Gradation Name } & \multicolumn{1}{c}{ Aggregate Sizes in $\mathbf{~ m m}$} & \multicolumn{3}{c}{ Gradation parameters } \\
& $\mathbf{1 2 . 5}$ & $\mathbf{1 0}$ & $\mathbf{6 . 7}$ & $\mathbf{4 . 7 5}$ & $\mathbf{D}_{\mathbf{6 0}}(\mathbf{m m}) \mathbf{D}_{\mathbf{1 0}}(\mathbf{m m})$ & $\mathbf{C}_{\mathbf{u}}$ \\
\hline G1 & 0 & 0 & 0 & $100 \%$ & 4.75 & 4.75 & 1.00 \\
$\mathrm{G} 3$ & 0 & $100 \%$ & 0 & 0 & 10.00 & 10.00 & 1.00 \\
$\mathrm{G} 4$ & $25 \%$ & $25 \%$ & $25 \%$ & $25 \%$ & 10.8 & 5.40 & 2.00 \\
G7 & 0 & $50 \%$ & $25 \%$ & $25 \%$ & 10.60 & 5.70 & 1.86 \\
\hline W/C ratio & \multicolumn{6}{c}{0.32} \\
\hline A/C ratio & \multicolumn{6}{c}{$3.5,4$ and 4.5} \\
\hline
\end{tabular}

Based on literatures percentage of aggregates were selected and to ensure the connectivity of pores coefficient of uniformity was maintained less than 8 .

All mixtures were produced in the laboratory using ordinary Portland cement of type I/II with constant water cement ratio of 0.32 . All mixtures were prepared in accordance with ASTM C192 [24] using virgin crushed igneous stone aggregates confirming to ASTM C33 [25] of uniform sizes. Type I/II ordinary Portland cement confirming to ASTM C 150 [26] standards and having specific gravity of 3.15 were used in all the mixtures. As per ASTM C29 [27] dry rodded unit weight of the aggregates were determined and were used in the design of mixtures using ACI [1] method of pervious concrete mix design.

\subsection{Methods}

\subsubsection{Specimen Preparations}

Cylinders of diameter $100 \mathrm{~mm}$ and height $200 \mathrm{~mm}$ were prepared to examine various properties of pervious concrete. Porosity, density, permeability, and unconfined compressive, were determined. Ingredients were weighted as per mix proportion, and then were put in the 
concrete mixer. Pan type concrete mixer was used for preparation of mixes (Fig 1). The mixing was done by first adding the aggregates and plasticizer in the mixer with a small amount of water so as to make aggregate wet, after 1 minute of mixing cement were added. After proper mixing of cement with aggregates, the remaining water was added and mixed thoroughly for about 90 seconds so as to obtain a uniform color of the mixture. The fresh mixture then transferred to moulds and was compacted using three different methods. Moulds were filled in three layers of equal size each layer were given compaction, each layer were scrapped slightly for better bonding with the next layer. Each surface was leveled properly before compaction. Compaction was done by three different methods: a) Temping using temping rod, b) Proctor hammer and c) using pneumatic compaction.

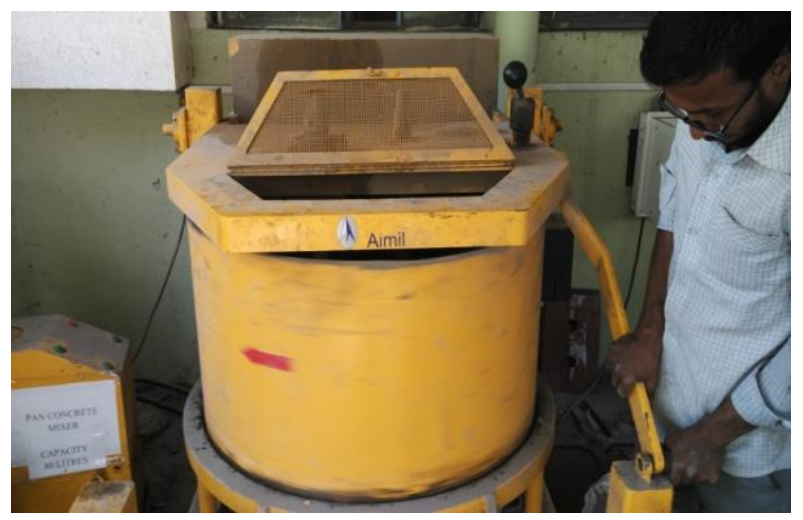

Figure 1 Mixing Process with Pan Mixer

\subsubsection{Specimen Preparations}

Three compaction methods a) Rodding b) Proctor Hammer c) Pneumatic vibration were used to study the effect of compaction methods on performance of pervious concrete. Specimens with different mixture proportions were prepared by rodding with cylindrical temping rod of $16 \mathrm{~mm}$ diameter and $0.6 \mathrm{~m}$ long as described in IS-516 [28]. Mixes were compacted using temping rod in three layers of equal size and by giving 25 numbers of blows. This method is a conventional method and leads to rod holes in the cylinders.

Proctor hammer temping was another type of compaction method employed for specimen preparation. A standard proctor hammer of mass $2.5 \mathrm{Kg}$ was used in sample production with 20 numbers of blows per layer was given. Previous studies [29] shown that the proctor hammer procedure simulates the field performance of pervious concrete in a better way than other methods of compaction.

Pneumatic vibration was given for 10 seconds by pneumatic hammer with special attachment as shown in Figure 2. Specially prepared attachment was used for circular specimen compaction, sizes of compaction plates were as per the dimensions of cylindrical moulds. Pneumatic hammer confirming to ASTM C1435 [30] was used. ASTM C1435 [30] is the standard specifies the requirements for the form and shape of the compaction tamping plate including tolerance. Standard specify the requirement for the type of the hammer. Minimum power input should be $900 \mathrm{~W}$, frequency at least $2000 \mathrm{impacts} / \mathrm{min}$ as per ASTM C1435 [30]. 


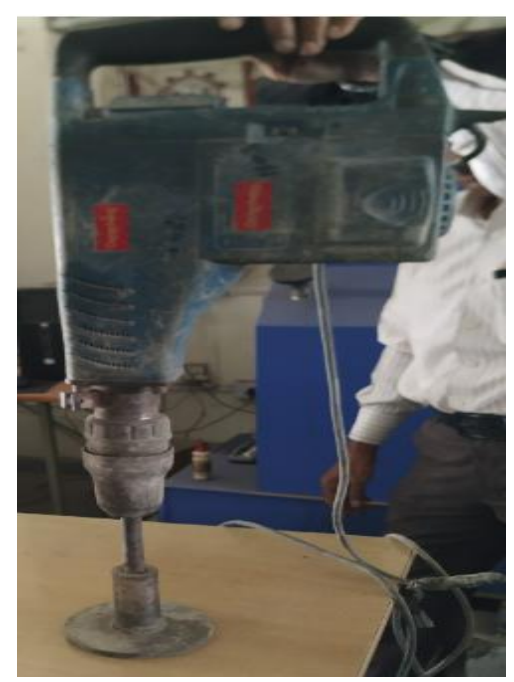

Figure 2 Pneumatic Compaction Hammer

\subsubsection{Testing}

The density $(\rho)$ and porosity $(\phi)$ of various PC specimens were determined according to procedure described in ASTM C1754-12 [31]. Porosity was calculated using submerged mass and oven dry mass using Equation (1)

$$
\emptyset=100 *\left[1-\frac{M d r y-M s u b}{V b * \rho w}\right]
$$

Where,

$\mathrm{M}_{\text {dry }} \quad=$ oven dry mass of specimen, $\mathrm{kg}$

$\mathrm{M}_{\text {sub }} \quad$ = submerged mass of specimen, $\mathrm{kg}$

$\mathrm{V}_{\mathrm{b}} \quad=$ bulk volume of specimen, $\mathrm{m}^{3}$

$\rho_{\mathrm{w}} \quad=$ density of water, $\mathrm{kg} / \mathrm{m}^{3}$

Permeability of PC specimens was determined using falling head permeameter, which was fabricated in laboratory for cylindrical specimen. The basic arrangement of permeameter is shown in Figure 3(a). Laboratory fabricated permeameter is made of PVC pipe with a piezometric tube fitted on it (Figure 3 (b)), graduations were marked on the pipe using a scale to the least count of $5 \mathrm{~mm}$. The diameter of PVC pipe was $100 \mathrm{~mm}$, which is equals to the diameter of cylindrical specimen, so as to accommodate the specimen properly. To ensure proper fixing of specimen inside the PVC pipe, PVC collar was attached to the PVC pipe, so as to insert the specimen properly inside the permeameter. Time duration $(\mathrm{t})$ was recorded for water to drop from falling head $\mathrm{h} 1$ to $\mathrm{h} 2$ by using stop watch. The coefficient of permeability was calculated using Equation (2)

$$
K=\frac{a l}{A t} * \ln \left(\frac{h 1}{h 2}\right)
$$

Where,

$\mathrm{K}=$ Coefficient of permeability, $\mathrm{mm} / \mathrm{s}$

$\mathrm{a} \quad=$ cross sectional area of specimen, $\mathrm{mm}^{2}$

$1=$ length of specimen, $\mathrm{mm}$ 
Influence of Compaction Methods on Functional and Structural Performance of Pervious Concrete

A $=$ cross sectional area of stand pipe, $\mathrm{mm}^{2}$

$\mathrm{t} \quad=$ time taken for water to flow from $\mathrm{h} 1$ to $\mathrm{h} 2$, seconds

$\mathrm{h}_{1} \quad=$ initial head of water, $\mathrm{mm}$

$\mathrm{h}_{2} \quad=$ final head of water, $\mathrm{mm}$

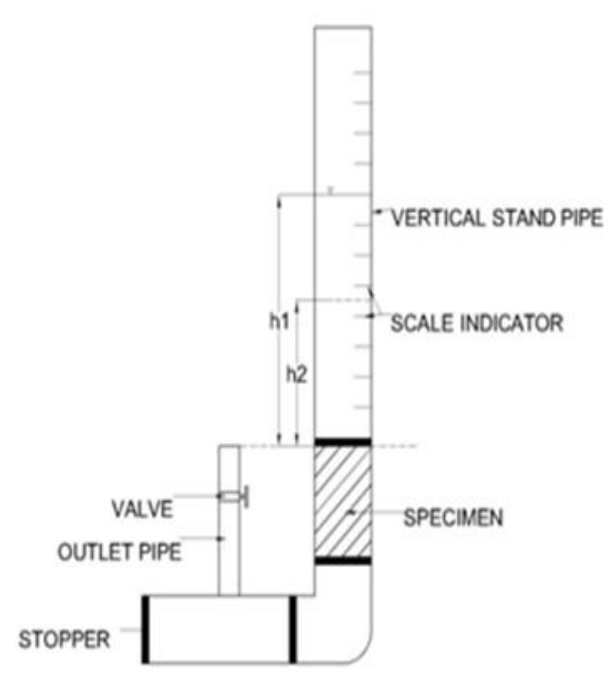

(a) Basic Arrangement

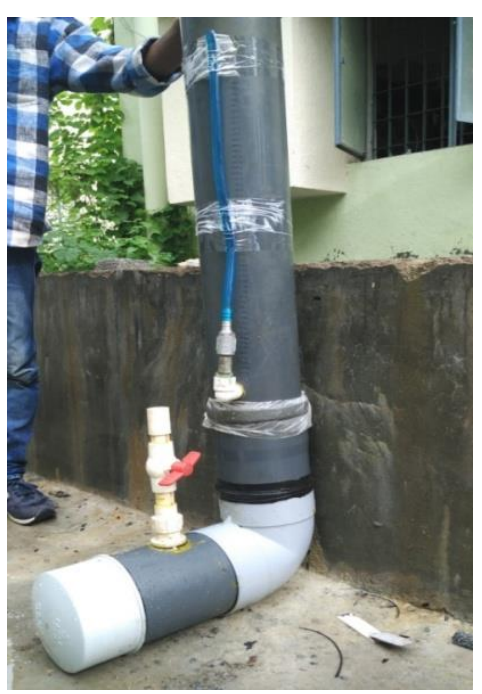

(b) Laboratory Fabricated

Figure 3 Falling Head Permeameter

The unconfined compressive strength of pervious concrete was determined in the laboratory by using electronic compression testing machine as per ASTM C39 [32]. Cylinders were tested by applying $0.233 \mathrm{Mpa} / \mathrm{sec}$ constant rate of stress. The experimental setup for compressive strength determination is shown in Figure 4.

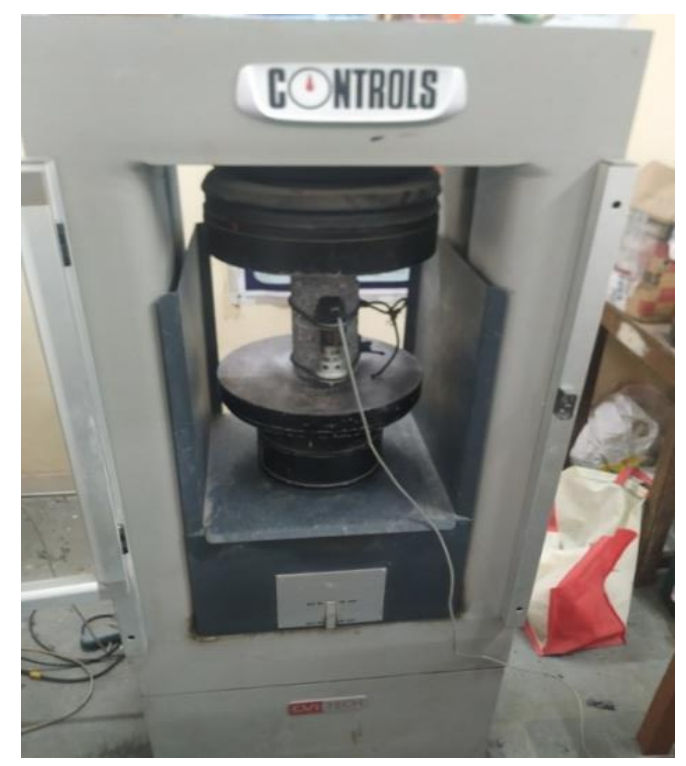

Figure 4 Compression Testing Machine Setup 


\section{RESULTS AND DISCUSSIONS}

\subsection{Density and Porosity}

The density and porosity were measured as per standard code ASTM C1754-12 [31]. Figure 5 shows the variation of average density with different types of compaction method and aggregate gradations employed in the production of pervious concrete specimens. It can be observed from the Figure 5, gradation G4 depicted highest density followed by G7 in all of the compaction method. This can be due to dense aggregate gradation of G4 while in case of G7 it was ternary. In single sized aggregate gradations G1 and G3, G3 depicted higher density than G1 in all the three compaction methods used in this study, this can be due to large aggregate size used in gradation G3 as compared to gradation G1. In all the four gradations of mixtures rodding method of compaction depicted lowest density as compared to other two methods of compaction. This can be due to lower amount of energy supplied by the temping rod used in the compaction process at the time of casting of specimens. On the other hand, pneumatic compaction method depicted highest density due to high amount of energy supplied during compaction.

Figure 6 shows the comparison of average porosity of gradations with different compaction method. As observed, gradation G4 depicted lowest porosity in all the three compaction methods compared to other gradation mixtures. This can be due to presence of aggregate of all the four sizes, in which the space created by larger aggregate sizes were filled by smaller sized aggregates, resulted in lower porosity. In single sized aggregate gradations G1 and G3, G3 depicted higher porosity than G1.

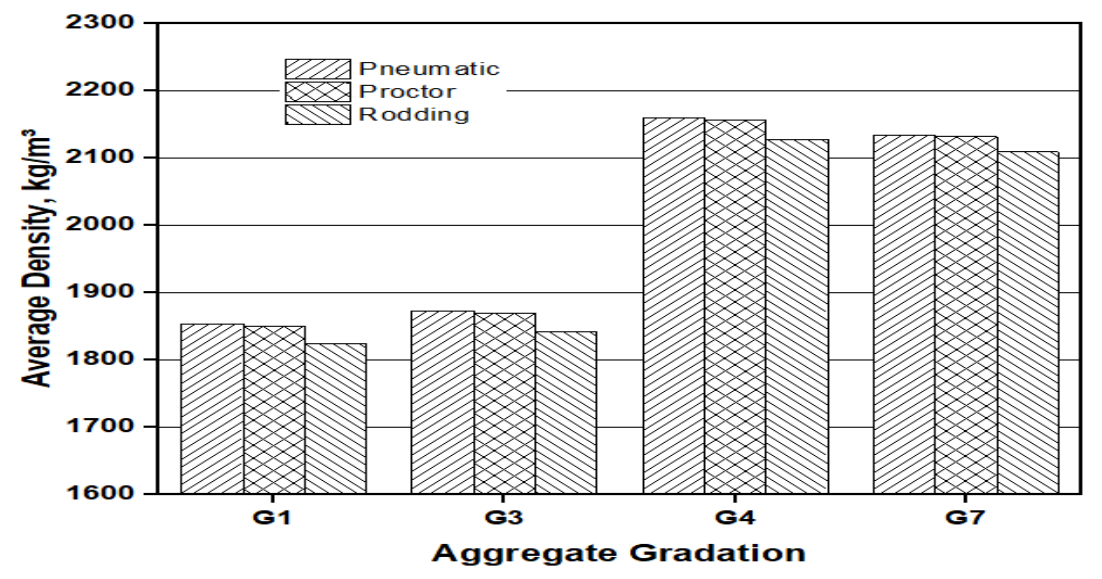

Figure 5 Average Density of Different Aggregate Gradation

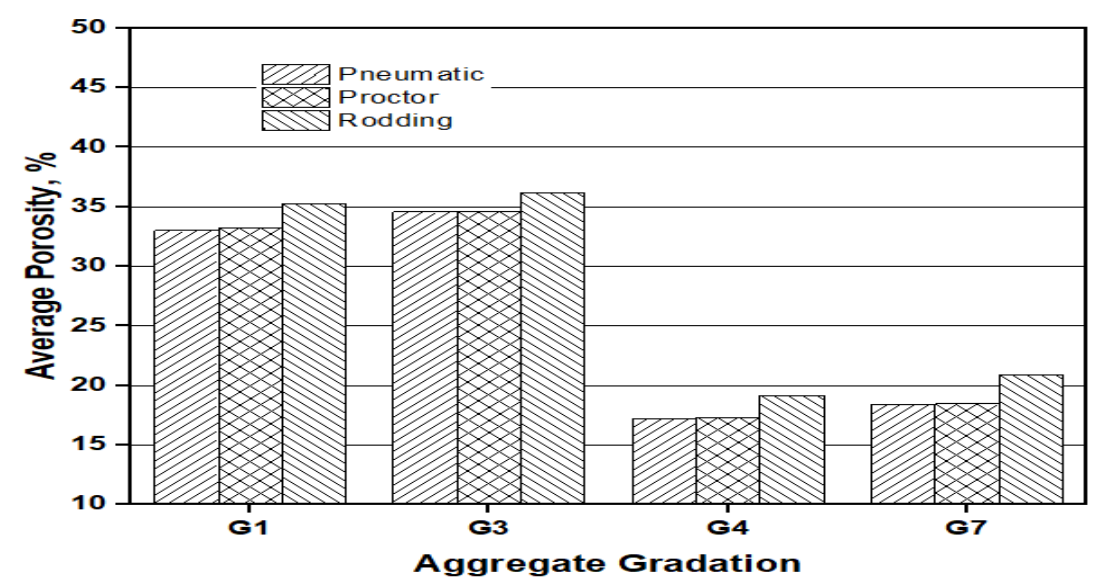

Figure 6 Average Porosity of Different Aggregate Gradation 
Influence of Compaction Methods on Functional and Structural Performance of Pervious Concrete

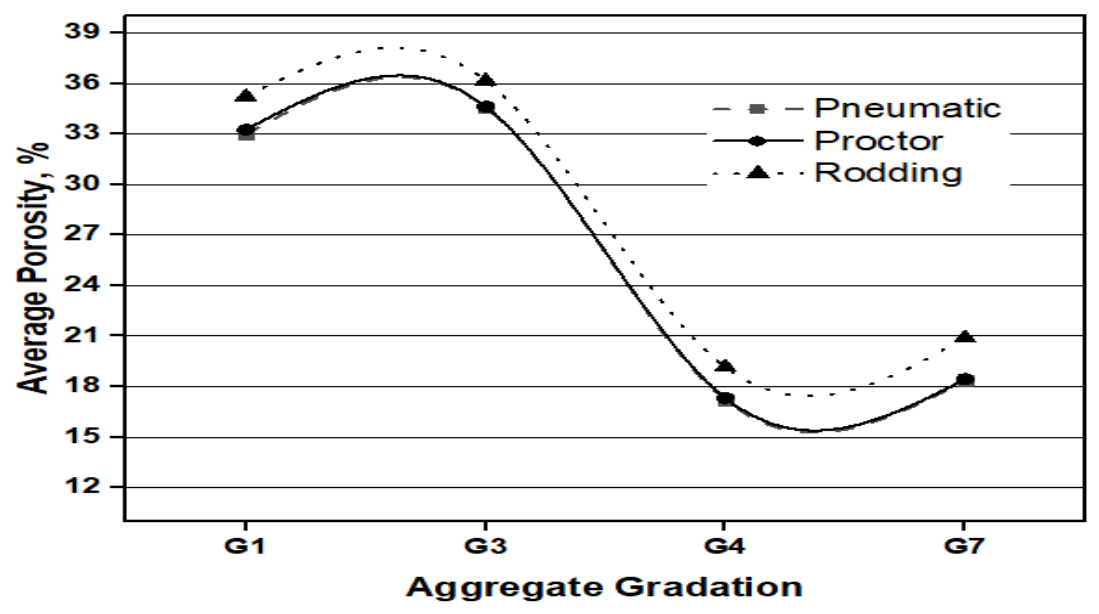

Figure 7 Comparison of Average Porosity

Figure 7 shows the comparison of compaction method on porosity of different gradations, it can be observed from Figure 7 pneumatic and proctor hammer type of compaction method depicted almost same porosity for all the gradation of mixtures, while rodding method depicted higher porosity compared to other two method of compaction.

\subsection{Permeability}

Permeability is one of the most important properties of PC that is essential in the functional as well as hydrological design of pervious concrete. It is the property by virtue of which water can flow though the connected pores inside any porous medium. Permeability can be measured by either using constant head method or falling head method. In this study, the permeability of different specimens was measure using falling head method. Figure 8 shows the permeability variation based on gradation and method of compaction.

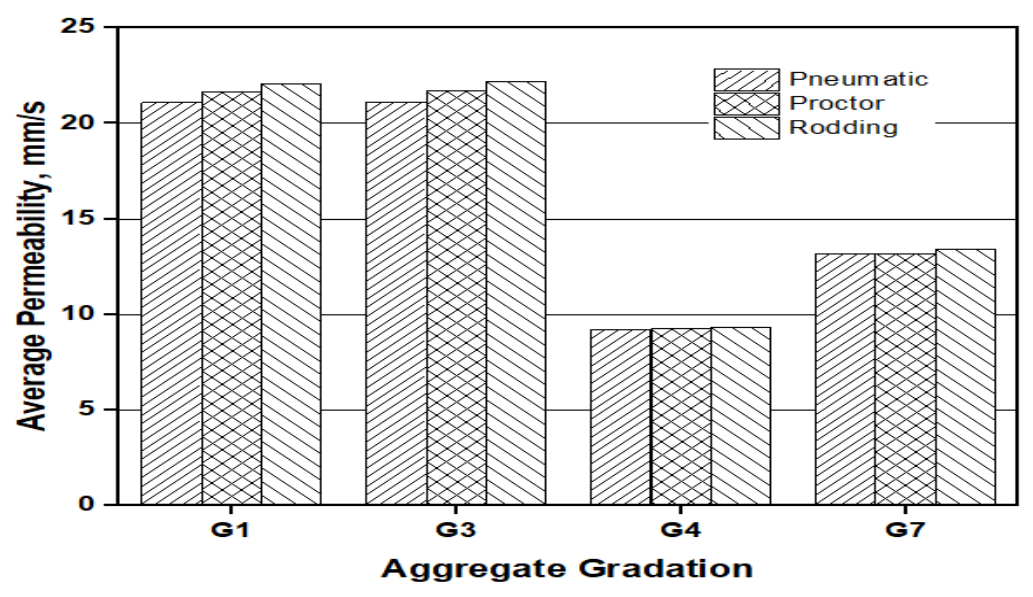

Figure 8 Average Permeability of Different Aggregate Gradation

\subsection{Compressive Strength}

Unconfined compressive strength test was performed to determine the load carrying capacity of pervious concrete specimens. The test was performed using Universal Testing Machine (UTM) in a controlled displacement mode with loading rate of $0.22 \mathrm{MPa} / \mathrm{s}$. Figure 9 shows the compressive strength variation based on aggregate gradations and compaction method. Gradation G4 depicted highest compressive strength due to well graded aggregate gradation. On the other hand, G3 single graded mixture depicted lowest compressive strength that can be due to large aggregate size of aggregates. In all the gradations pneumatic compaction method 
depicted highest compressive strength in all the gradations. Comparison of average compressive strength with compaction method is shown in Figure 10. Gradation G4 and G7 depicted higher variation in the value of compressive strength in all the three compaction methods. However, gradation G1 and G3 depicted less variation in compressive strength with different compaction method.

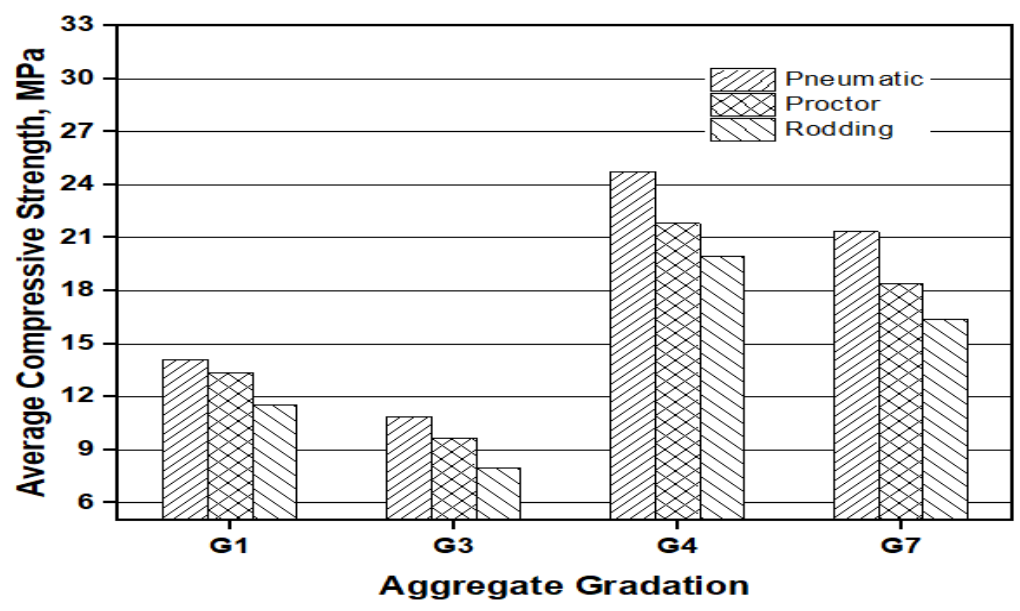

Figure 9 Average Compressive Strength of Different Aggregate Gradation

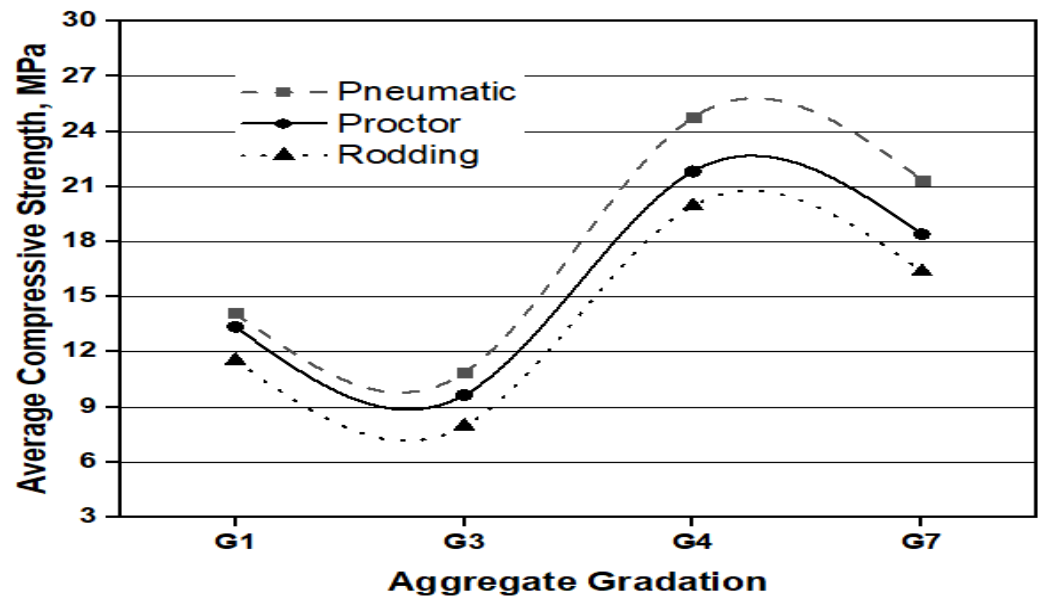

Figure 10 Comparison of Compressive Strength

\subsection{Relationship between Average Density and Average Compressive Strength}

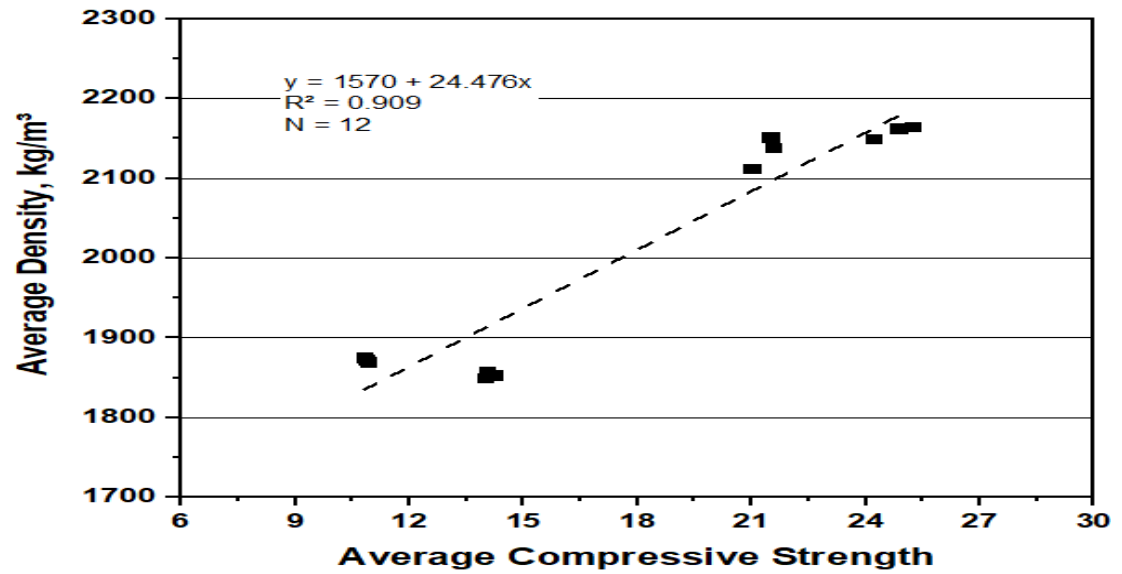

Figure 11 Relationship between Average Density and Average Compressive Strength 
The relation between average density and average compressive strength is shown in Figure 11. A straight line relationship was observed in density and compressive strength with goodness of fit $\left(R^{2}=0.909\right)$, which depicted excellent relation with each other.

\section{CONCLUSION}

Based on the results of this limited study that was developed to potentially determine the most appropriate method that can produce pervious concrete specimen that can depict optimum functional and structural performance, the following conclusion can be made.

- The specimen produced by rodding method had a greater degree of variability than other methods of compaction. The major reason of the increased variability was the creation of rod holes it the specimen at the time of casting. On the other hand, pneumatic hammer produced specimens with lowest degree of variability.

- Pneumatic hammer compaction method specimens depicted higher density than other method of compaction, although a very small variation was observed with proctor hammer compaction method

- Among all the three compaction methods percentage variation was higher in porosity as compared to permeability, which ultimately affects the other mechanical properties of pervious concrete

- Pneumatic hammer compaction method depicted higher compressive strength as compared to other method of compaction, and higher variation in compressive strength was observed among all the three methods of compaction

- It can be concluded that specimen produced by pneumatic compaction method depicted optimum structural as well as functional properties

- Relation between density and compressive strength was excellent with $\mathrm{R}^{2}=0.909$

\section{REFERENCES}

[1] ACI 522R-2010, Report on Pervious Concrete, American Concrete Institute, 2010.

[2] NMRCA-Concrete in Practice-38 (CIP-38), National Ready Mix Concrete Association (NMRCA).

[3] Haselbach L. M., Valavala S., and Montes F., Permeability Predictions for Sand Clogged Portland Cement Pervious Concrete Pavement Systems, J. Environ. Manage., 81, 2005, pp. 42-49 (Elsevier).

[4] Lim E., Twan K. H. and Fwa T. F., Effect of Mix Proportion on Strength and Permeability of Pervious Concrete for Use in Pavement, Proceedings of the Eastern Asia Society for Transportation Studies, vol. 9, 2013.

[5] Li H., Kayhanian M., and Harvey J. T., Comparative Field Permeability Measurement of Permeable Pavements Using ASTM C1701 and NCAT Permeameter Methods, J. Environ. Manage., 118, 2013, pp. 144-152.

[6] Luck J. D., Workman S. R., Coyne M. S. and Higgins S. F., Solid Material Retention and Nutrient Reduction Properties of Pervious Concrete Mixtures, Biosyst. Eng. 100, 2008, pp. 401-408.

[7] Montes F., Valavala S., and Haselbach L. M., A New Test Method for Porosity Measurements of Portland Cement Pervious Concrete, J. ASTM Int., 2 (1), 2005, pp. 1-13.

[8] G. N. McCain and M. M. Dewoolkar, "Strength and Permeability Characteristics of Porous Concrete Pavements", Transp. Res. Board, 1-13, 2009. 
[9] Yang J. and Jiang G., Experimental Study on Properties of Pervious Concrete Pavement Materials, Cem. Concr. Res., 33, 2002, pp. 381-386.

[10] O. Deo, "Influence of Material Structure on the Structural and Environmental Properties of Pervious Concretes" (Ph.D. Dissertation), Clarkson University, SA, 2011.

[11] Tennis P. D., Leming M. L. and Akers D. J., Pervious Concrete Pavements, EB302.02, Portland Cement Association, Skokie, Illinois, and National Ready Mixed Concrete Association, Silver Spring, Maryland, USA, 2004, pp. 36.

[12] Kevern J. T., Wang K. and Schaefer V. R., Effect of Coarse Aggregate on the Freeze- Thaw Durability of Pervious Concrete, J. Mater. Civ. Eng. 22 (5), 2010, pp.469-475.

[13] Jain A. K. and Chouhan J. S., Effect of Shape of Aggregate on Compressive Strength and Permeability Properties of Pervious Concrete, Int. J. Adv. Eng. Res. Stud. 1, 2011,pp. 120126.

[14] Chindaprasrit P., Hatanaka S., Chareerat T., Mishima N., and Yuasa Y., Cement Paste Characteristics and Porous Concrete Properties, Constr. Build. Mater. 22, 2008, pp. 894-901.

[15] Martin III W. D., Kaye N. B. and Putman B. J., Impact of Vertical Porosity Distribution on the Permeability of Pervious Concrete, Constr. Build. Mater., 59, 2014, pp. 78- 84.

[16] Putman B. J. and Neptune A. I., Comparison of Test Specimen Preparation Techniques for Pervious Concrete Pavements, Constr. Build. Mater. 25, 2011, pp. 3480-3485,.

[17] Jimma B.E., and Rangaraju P.R., Chemical admixtures dose optimization in pervious concrete paste selection - A statistical approach, Construction and Building Materials, Vol.101, 2015, pp. 1047-1058

[18] Ghafoori N., and Dutta S., Laboratory Investigation of Compacted No-Fines Concrete for Paving Materials, Journal of Materials in Civil Engineering, Vol. 7, issue. 3, 1995, pp. 183191.

[19] Shu X., Huang B., Wu H., Dong Q., Burdette E. G., Performance comparison of laboratory and field produced pervious concrete mixtures, Construction and Building Materials, Vol. 25, 2011, pp. 3187-3192.

[20] Kevern J.T., Schaefer V.R., and Wang K., Evaluation of pervious concrete workability using gyratory compaction, Journal of Materials in Civil Engineering, Vol. 21, 2009, pp. 764-770.

[21] A. K. Chandrappa and K.P. Biligiri, "Pervious concrete as a sustainable pavement material Research findings and future prospects: a state-of-the-art review", Construction and Building Materials, Vol. 111, pp. 262-274, 2016.

[22] C. Lian, and Y. Zhuge, "Optimum mix design of enhanced permeable concrete - An experimental investigation", Construction and Building Materials, Vol. 24, pp.2664-2671, 2010.

[23] Yahia A., and Kabagire D., New approach to proportion pervious concrete, Construction and Building Materials, 2014, Vol. 62, pp. 38-46.

[24] ASTM Standard Specification for Making and Curing Concrete Test Specimens in the Laboratory, ASTM C192/C192M, West Conshohocken, PA 19428-2959, United States of America, 2018.

[25] ASTM Standard Specification for Concrete Aggregates, ASTM C33/C33M, West Conshohocken, PA 19428-2959, United States of America, 2018.

[26] ASTM Standard Specification for Portland Cement, ASTM C150/C150M-09, West Conshohocken, PA 19428-2959, United States of America, 2009.

[27] ASTM Standard Test Method for Bulk Density Unit Weight and Voids in the Aggregates, ASTM C29/C29M-17, West Conshohocken, PA 19428-2959, United States of America, 2017. 
Influence of Compaction Methods on Functional and Structural Performance of Pervious Concrete

[28] IS 516 Indian Standard, Methods of test for Strength of Concrete, New Delhi, India, 1959.

[29] Tratik T., Chylik R., Biley P., and Fladr J., Analysis of Laboratory Compaction Methods of Roller Compacted Concrete, Mater. Science. \& Engg., 236, 2017, pp. 012-029.

[30] ASTM Standard Practice for Molding Roller Compacted Concrete in Cylindrical Molds Using a Vibrating Hammer, ASTM C1435/C1435M-14, West Conshohocken, PA 19428-2959, United States of America, 2014.

[31] ASTM Standard Test Method for Density and Void Content of Hardened Pervious Concrete, ASTM C1754/C1754M-12, West Conshohocken, PA 19428-2959, United States of America, 2012.

[32] ASTM Standard Test Method for Compressive Strength of Cylindrical Concrete Specimens, ASTM C39/C39M-18, West Conshohocken, PA 19428-2959, United States of America, 2018. 